Original Research

\title{
The Effect of Feeding Horses a High Fiber Diet With or Without Exogenous Fibrolytic Enzymes Supplementation on Nutrient Digestion, Blood Chemistry, Fecal Coliform Count, and In Vitro Fecal Fermentation
}

\author{
Abdelfattah Z.M. Salem ${ }^{a, *}$, Mona M.Y. Elghandour ${ }^{a}$, Ahmed E. Kholif ${ }^{b}$, Nicholas E. Odongo ${ }^{c}$, \\ Francisco J.P. Jiménez ${ }^{d}$, Roberto Montes-de-Oca ${ }^{a}$, Ignacio A. Domínguez ${ }^{a}$, Jorge A. Dibarrat ${ }^{a}$ \\ a Facultad de Medicina Veterinaria y Zootecnia, Universidad Autónoma del Estado de México, Toluca, México \\ ${ }^{\mathrm{b}}$ Dairy Science Department, National Research Centre, Giza, Egypt \\ ${ }^{\mathrm{c}}$ Department of Animal Sciences, School of Agriculture and Environmental Sciences, Pwani University, Kilifi, Kenya \\ d Instituto de Ciencias Agropecuarias, Universidad Autónoma de Hidalgo, Rancho Universitario, Tulancingo, Hidalgo, México
}

\section{A R T I C L E I N F O}

\section{Article history:}

Received 22 May 2015

Received in revised form 6 July 2015

Accepted 22 July 2015

Available online 29 July 2015

\section{Keywords:}

Coliform

Enzyme

Feed utilization

Horse

\begin{abstract}
A B S T R A C T
Sixteen Quarter Horse mares (450 to $500-\mathrm{kg}$ body weight) were used in a complete randomized design to determine the effects of feeding a high fiber diet with or without exogenous fibrolytic enzymes on nutrient digestion, blood chemistry, fecal coliform count, and in vitro fecal fermentation. The treatments comprised feeding the horses (1) a basal diet without enzyme addition (control); (2) control diet plus cellulase at $10 \mathrm{~mL} / \mathrm{mare} /$ d (CELL); (3) control diet plus xylanase at $10 \mathrm{~mL} / \mathrm{mare} / \mathrm{d}$ (XYL); or (4) control diet plus a mixture of $5 \mathrm{~mL}$ cellulase and $5 \mathrm{~mL}$ xylanase/mare/d (CX). The basal concentrate diet consisted of a mixture of $50 \%$ commercial concentrate and $50 \%$ wheat bran fed at $4 \mathrm{~kg} /$ horse, offered twice daily at 04:00 and 16:00 hours, and oat straw offered ad libitum at 05:00 and 17:00 hours. The enzyme allocation for each day was mixed with $1 \mathrm{~kg}$ of concentrate diet at 04:00 hours, and the experiment lasted for 15 days comprising 10 days of adaptation and 5 days for sample collection. The in vitro cecal fermentation with addition of $2 \mu \mathrm{L} / \mathrm{g}$ dry matter (DM) of each enzyme (CELL, XYL, and CX) to a basal diet of oat straw and concentrates mixture $(1: 1 \mathrm{DM})$ as a substrate was carried out. The mares fed enzyme-supplemented diets had greater $(P<.01)$ oat straw and total nutrients intakes compared with the control diet. Feeding enzyme-supplemented diets increased total nutrients digestibility $(P<.05)$ and blood total protein $(P=.0277)$ compared with the control. Feeding XYL-supplemented diet increased blood alanine transaminase and aspartate aminotransferase concentrations $(P<.05)$ compared with control treatment. Lower fecal coliform count was obtained $(P=.0114)$ with mares fed $C X$ diet compared with control mares. The XYL and CX treatments had decreased asymptotic gas production (GP) $(P=$ $.0173)$ with lower rate of GP $(P=.0412)$ compared with CELL treatment. CELL and XYL treatments had decreased $(P=.0394)$ lag times compared with control and $C X$ treatments. At 24 hours of incubation, CELL and XYL treatments decreased methane production $(P=$ $.0131)$, whereas $C X$ treatment increased its production at 48 hours $(P=.0202)$ compared with control treatment. No effect was observed $(P>.05)$ with enzymes addition on carbon dioxide production at different hours of incubation compared with control treatment. Higher in vitro DM degradability values $(P=.0092)$ were obtained with the enzyme
\end{abstract}

\footnotetext{
* Corresponding author at: Abdelfattah Z.M. Salem, Universidad

Autónoma del Estado de México, 50000 Toluca, Mexico.

E-mail address: asalem70@yahoo.com (A.Z.M. Salem).
} 
treatments compared with control treatment. Fermentation pH was lower $(P=.0396)$ with CX treatment and increased with CELL treatment compared with the control and XYL, showing a greater $\mathrm{pH}$ with CELL than the other treatments. It can be concluded that addition of fibrolytic enzymes at $10 \mathrm{~mL} / \mathrm{mare} / \mathrm{d}$ improved feed intake and nutrients digestibility without affecting mare's health.

(c) 2015 Elsevier Inc. All rights reserved.

\section{Introduction}

Horses are free-ranging herbivores adapted to eating large amounts of high fiber diets for the normal function of the equine digestive system. However, pathologies such as gastric ulceration, laminitis, hindgut acidosis, and colic are associated with feeding diets high in cereal grain [1]. Therefore, there is increasing interest in feeding fiber-based diets with low levels of starch and sugar to meet the energy demands of the horse and reduce incidences of such disorders. Feeding horses a minimum of $1 \%$ of their body weights (BWs) as fibrous feedstuffs can minimize occurrence of colic, gastric ulcers, hindgut acidosis, and stereotypical behaviors [2].

Forage feeds have low protein content and low nutrients digestibility [3,4]. There is a need for developing new feeding strategies to meet horse nutrient requirements while maintaining gut health and integrity. In ruminant diets, exogenous fibrolytic enzymes have been shown to improve the digestion of plant fiber fractions by improving ruminal fermentation working synergetically with endogenous rumen microbial enzymes [4]. The large intestine of the horse is a fermentation system similar to the rumen [5]. Microorganisms living in the rumen of ruminant animals and in the cecum of horses give them the ability to breakdown fibers by microbial fermentation to meet energy demands [6].

Numerous studies have been conducted with ruminants to investigate the potential benefits of exogenous fibrolytic enzyme supplementation in improving total tract nutrient digestibilities [7]. Supplementing the diet of horses with exogenous fibrolytic enzymes has gained substantial interest in recent years $[6,8]$. However, the potential of exogenous enzymes to enhance the digestion of plant structural carbohydrates in the hindgut of the equine working in synergism with endogenous microorganisms is inconclusive [8]. Hainze et al [8] fed horses a diet of grass hay with textured concentrate, pelleted concentrate, whole oats, or alfalfa-lucerne (Medicago sativa) supplemented with cellulase and reported that cellulase administration improved the digestion of neutral detergent fiber (NDF) and acid detergent fiber (ADF) in the oats and textured feeds, but decreased the digestion of NDF and ADF in the alfalfa-lucerne. In contrast, Murray et al [9] reported a significant reduction in in vivo digestibility of the fibrous fractions of enzyme-treated high-temperature dried lucerne and ensiled lucerne. Similarly, O'Connor-Robison et al [6] fed Arabian geldings a hay-based diet supplemented with cellulase and noted that cellulase addition decreased digestion of the fiber components.

Therefore, the aim of the present study was to determine the effect of feeding cellulase, xylanase, and their mixture
$(1: 1 \mathrm{vol} / \mathrm{vol})$ on nutrient digestion, blood chemistry, fecal coliform count, and in vitro fecal fermentation in horses fed a high fiber-based diet.

\section{Materials and Methods}

All procedures involved in handling animals during the experimental period were conducted according to the official Mexican standard of animals care number NOM-051-ZOO-1995.

\subsection{Study Location}

The experiment was conducted at the Sierra Morelos National Park, De la Barrera Teresona, Toluca, State of Mexico, Mexico. The park is at an altitude of $2,715 \mathrm{~m}$ above sea level. The climate in this area is temperate, semihumid with rains in summer. The average annual temperature is $15^{\circ} \mathrm{C}$ with a maximum of $37^{\circ} \mathrm{C}$ and a minimum of $3^{\circ} \mathrm{C}$. The average annual rainfall is $970 \mathrm{~mm}$ with prevailing winds from the north.

\subsection{Treatments and Experimental Design}

Sixteen Quarter Horse mares (450 to 500-kg BW; 10-12 years of age) were used in this study. In a complete randomized design, four animals were randomly assigned to each of the treatments which were fed individually in $3.6 \mathrm{~m} \times 3.6 \mathrm{~m}$ stalls. The basal concentrate diet consisted of a mixture of $50 \%$ commercial concentrate ( $2 \mathrm{~kg}$ of total diet/ horse) (Pell Rol Cuarto de Milla, Mexico City, Mexico) and $50 \%$ wheat bran plus oat straw ( $2 \mathrm{~kg}$ of total diet/horse). The basal concentrate diet ( $4 \mathrm{~kg}$ of total diet/horse) was fed twice daily at 04:00 and 16:00 hours, whereas the forage component of oat straw was offered ad libitum two times daily at 05:00 and 17:00 hours. Diets were balanced to cover animal's requirements according to nutrient requirements of horses of National Research Council [2] as $0.63-\mathrm{kg}$ crude protein $(\mathrm{CP})+16.39$ Mcal digestible energy daily. The concentrates mixture contained (dry matter [DM] g/kg) organic matter (OM): 901.8, CP: 112.0, NDF: 511.0, and ADF: 202.8. The wheat bran contained (DM g/kg) OM: 931.0, CP: 169.8, NDF: 460.0, and ADF: 131.2. The oat straw contained (DM g/kg) OM: 929.4, CP: 26.7, NDF: 668.7, and ADF: 405.0. Horses were given 3 to 4 hours in the stalls to allow sufficient time for feeding. When not in the stalls, horses were maintained on a drylot for socialization and exercise.

The treatments comprised feeding the horses (1) both concentrates and oat straw without enzyme addition (control); (2) control diet plus cellulase at $10 \mathrm{~mL} / \mathrm{mare} / \mathrm{d}$ (CELL); (3) control diet plus xylanase at $10 \mathrm{~mL} / \mathrm{mare} / \mathrm{d}$ 
(XYL); or (4) control diet plus a mixture of cellulase and xylanase at $5 \mathrm{~mL}$ each/mare/d (CX). The experiment lasted for 15 days comprising 10 days of adaptation and 5 days for sample collection. The enzyme allocation for each day was sprayed and mixed with $1 \mathrm{~kg}$ of concentrate component at 04:00 hours and left for animal for 1 hour to ensure total consumption before adding the remaining $3 \mathrm{~kg}$ of concentrate. Water and salt were available ad libitum.

\subsection{Enzyme Activity}

The activities of the fibrolytic enzymes (Dyadic PLUS, Dyadic international, Inc, Jupiter, FL, USA) celluase plus and xylanase plus were determined as described by Robyt and Whelan [10]. Briefly, the enzyme products were assayed for endoglucanase and xylanase activity by catalytic hydrolysis of xylan from oat spelt and determining the liberated reducing groups using alkaline copper reagent. The cellulase product contained 30,000 to 36,000 units of cellulase $/ \mathrm{mL}$ and 7,500 to 10,000 units of beta-glucanase $/ \mathrm{mL}$. The xylanase product contained 34,000 to 41,000 units of xylanase/ $\mathrm{mL}, 12,000$ to 15,000 units of beta-glucanase/mL, and 45,000 to 55,000 units of cellulase/mL.

\subsection{Nutrient Digestibility}

For feed intake determination, the individual amount of feed offered was recorded daily and orts were collected and weighed daily throughout the experimental period. During the adaptation period (i.e., first 10 days), horses were trained for feed and fecal collections. On collection days (i.e., last 5 days), fecal samples were collected daily with rectal grab at 4-hour intervals and pooled for each mare. Daily pooled individual feces samples were analyzed for $\mathrm{DM}, \mathrm{OM}, \mathrm{CP}, \mathrm{NDF}, \mathrm{ADF}$, and acid insoluble ash (AIA) concentrations. Additionally, feeds were sampled daily and dried at $60^{\circ} \mathrm{C}$ to constant weight and stored for later chemical analysis for DM, OM, CP, NDF, ADF, and AIA concentrations. Apparent nutrient digestibilities were calculated using AIA concentrations as described by Agazzi et al [11] using the following equation:

\section{Apparent nutrient digestibility}

$$
=100-\left(100 \times \frac{\% \text { AIA in feed } \times \% \text { component in feces }}{\% \text { AIA in feces } \times \% \text { component in feed }}\right)
$$

For each nutrient digestibility within each treatment, 20 samples ( 4 mares $\times 5$ days) were applied independently for the mentioned equation.

At day 0 (the day before experiment beginning-no enzyme was fed) and also on the last day of the experiment, one sample of rectal feces from each mare was collected and put into sealable plastic bags and stored at $4^{\circ} \mathrm{C}$ for analysis of total coliform count.

Dried feed, orts, and feces samples were ground through a Wiley mill (Arthur H. Thomas, Philadelphia, PA, USA) using a 2-mm screen and analyzed for DM (\#930.15) and $\mathrm{N}$ (\#954.01) according to Association of Official Analytical Chemists [12]. Neutral detergent fiber and ADF were analyzed according to Van Soest et al [13]. Acid insoluble ash concentrations in feed and fecal samples were determined using the method of Van Keulen and Young [14].

\subsection{Blood Sampling and Analysis}

On the last day of the experiment (i.e., day 15), all mares of each treatments (i.e., four mares/treatment) were sampled for blood. The blood was collected from the jugular vein before feeding into a $10-\mathrm{mL}$ clean dry tube, with anticoagulants. Blood samples were centrifuged at $4,000 \times g$ at $4^{\circ} \mathrm{C}$ for 20 minutes. Serum was separated into $2-\mathrm{mL}$ clean dried Eppendorf tubes and frozen at $-20^{\circ} \mathrm{C}$ until analysis. The serum samples were analyzed spectrophotometrically using a BTS 350 Chemistry System Analyzer (Instrumentation Laboratory, Mexico City, Mexico) and IL test's using specific kits for concentrations of total protein (Cat.\# 0018481300), urea (Cat.\# 0018480400), alanine transaminase (ALT; Cat.\# 0018480700), aspartate aminotransferase (AST; Cat.\# 0018480800), glucose (Cat.\# 0018480000), creatinine (Cat.\# 0018480900), calcium (Cat.\# 0018258840), phosphorus (Cat.\# 0018481900), magnesium (Cat.\# 0018481600), and gamma-glutamyl transpeptidase (GGT, Cat.\# 0018480785).

\subsection{Coliform Isolation and Quantification}

Approximately $150 \mathrm{~g}$ of fecal samples were collected at days 0 and 15 from each mare as described by Weaver et al [15] and placed in sterile plastic bags and taken to the laboratory. The fresh fecal samples were thoroughly mixed in the plastic bags, and $1 \mathrm{~g}$ was taken for coliform count by membrane filtration. Briefly, the 1-g sample was transferred into a $120-\mathrm{mL}$ diluent bottle containing $99 \mathrm{~mL}$ of $0.31 \mathrm{mmol} \mathrm{KH}_{2} \mathrm{PO}_{4} / \mathrm{L}$ buffer solution and shaken vigorously by hand for approximately 60 seconds before making serial dilutions for plating by membrane filtration. Membranes were placed on m-TEC agar (m-TEC HiCrome Agar, SigmaAldrich, Mexico City, Mexico) and incubated for 24 hours at $44.5^{\circ} \mathrm{C}$ in a water bath before counting yellow colonies typical of Escherichia coli.

\subsection{In Vitro Fecal Incubations}

The basal diet of oat straw and the 1:1 mixture of the concentrates that was fed to horses in the in vivo study were used as a substrate for the in vitro study. With the exception of the preparation of the microbial inocula, the method of Theodorou et al [16] was used to measure gas production (GP). On the last day of the in vivo experiment, fecal samples were collected directly from the rectum of each horse and a composite sample of each treatment obtained for the in vitro incubation. A representative sample of the composite fecal contents for each treatment was mixed with the Goering and Van Soest [17] buffer solution without trypticase in the ratio of 1:4 to form four incubation media. The formed incubation media were mixed and strained through four layers of cheesecloth into a flask with an $\mathrm{O}_{2}$-free headspace. The fecal content mixed with the culture media were used to inoculate three identical runs of incubation in bottles containing $1 \mathrm{~g}$ DM of substrate (a 1:1 mixture of concentrates plus oat straw). Enzyme (CELL, XYL, and CX) was added at $2 \mu \mathrm{L} / \mathrm{g}$ DM of incubated substrates. 
Thirty-six bottles ( 3 replicates $\times 4$ treatments $\times 3$ runs) plus three bottles without substrate and enzyme as blank were used for GP. Once all bottles were filled, bottles were flushed with carbon dioxide $\left(\mathrm{CO}_{2}\right)$ and immediately closed with rubber stoppers, shaken and placed in the incubator at $39^{\circ} \mathrm{C}$. Gas production, methane $\left(\mathrm{CH}_{4}\right)$ production, and $\mathrm{CO}_{2}$ production were recorded at $2,4,6,8,10,12,24$, and 48 hours after inoculation. Gas production was recorded using the pressure reading technique (Extech instruments, Waltham, CT, USA) of Theodorou et al [16], whereas the $\mathrm{CH}_{4}$ and $\mathrm{CO}_{2}$ productions were recorded using Gas-Pro detector (Gas Analyzer CROWCON Model Tetra3, Abingdon, UK).

At the end of incubation after 48 hours, bottles were uncapped and the $\mathrm{pH}$ was measured using a digital $\mathrm{pH}$ meter (Conductronic pH15, Puebla, Mexico). After pH measurement, the content of each bottle was filtered under vacuum through glass crucibles with a sintered filter (coarse porosity no. 1, pore size 100-160 $\mu \mathrm{m}$; Pyrex, Stone, UK). Fermentation residues were dried at $65^{\circ} \mathrm{C}$ for 72 hours overnight to estimate DM degradability (DMD), with loss in weight after drying being the measure of degradable DM.

For estimating kinetic parameters of GP, results of GP ( $\mathrm{mL} / \mathrm{g} \mathrm{DM})$ were fitted using the NLIN option of SAS [18] according to France et al [19] as:

$A=b \times\left(1-e^{-c(t-L)}\right)$

where $\mathrm{A}$ is the volume of GP at time $t ; b$ is the asymptotic GP $(\mathrm{mL} / \mathrm{g} \mathrm{DM}) ; c$ is the rate of GP $(/ \mathrm{h})$, and $L(\mathrm{~h})$ is the discrete lag time before GP. Metabolizable energy (ME, MJ/ $\mathrm{kg}$ DM) and in vitro OM digestibility (OMD, $\mathrm{mg} / \mathrm{g} \mathrm{DM}$ ) were estimated according to Menke et al [20]. The partitioning factor at 24 hours of incubation $\left(\mathrm{PF}_{24}\right)$, as a measure of fermentation efficiency, was calculated as the ratio of in vitro DMD (mg/g DM) to the volume of gas $(\mathrm{mL})$ produced at 24 hours according to Blümmel et al [21]. Gas yields $\left(\mathrm{GY}_{24}\right)$ were calculated as the volume of gas produced after 24 hours ( $\mathrm{mL}$ gas/g DM) of incubation divided by the amount of DMD $(\mathrm{g})$ as: gas yields $\left(\mathrm{GY}_{24}\right)=\mathrm{mL}$ gas per g DM/g DMD. Short-chain fatty acids (SCFA) were calculated according to Getachew et al [22]. Microbial crude protein (MCP) production was calculated as by Blümmel et al [21].

\subsection{Statistical Analyses}

All data were analyzed as a completely randomized design using PROC MIXED of SAS [18]. The statistical model was $Y_{i j}=\mu+E_{j}+\varepsilon_{i j}$, where $Y_{i j}$ represents every observation of the $i$ th animal fed in the $j$ th enzyme product, $\mu$ is the general mean, $E_{j}$ is the enzyme product, and $\varepsilon_{i j}$ is the experimental error.

However, total coliform counts were transformed to $\log _{10}$ per gram of feces before analysis, and data of fecal in vitro GP of each of the three runs within the same sample of the substrate were averaged before statistical analysis.

Tukey test was used for multiple comparisons of mean values for each parameter. Significance was declared at a level of $P<.05$, and the absence of effect should be stated as $P>.05$.

\section{Results}

\subsection{Feed Intake and Nutrient Digestibility}

The mares fed enzyme-supplemented diets had greater $(P<.01)$ oat straw and total nutrient intakes compared with the control diet. Moreover, feeding enzymesupplemented diets increased total nutrients digestibility $(P<.05)$ compared with the control diet. Mares fed CELL diet had the highest $\mathrm{CP}$ digestibility $(P<.05)$ compared with mares fed other diets (Table 1 ).

Table 1

Feed intake and nutrient digestibility of the diets supplemented with cellulase, xylanase, and cellulase + xylanase $(1: 1$ vol/vol) enzymes in mares $(\mathrm{n}=4)$.

\begin{tabular}{|c|c|c|c|c|c|c|}
\hline \multirow[t]{2}{*}{ Items } & \multicolumn{4}{|l|}{ Diets } & \multirow[t]{2}{*}{ SEM } & \multirow[t]{2}{*}{$P$ Value } \\
\hline & Control & CELL & XYL & $\mathrm{CX}$ & & \\
\hline \multicolumn{7}{|l|}{ Oat straw intake $(\mathrm{kg} / \mathrm{d})$} \\
\hline Dry matter & $5.67^{\mathrm{b}}$ & $10.36^{\mathrm{a}}$ & $10.40^{\mathrm{a}}$ & $9.46^{\mathrm{a}}$ & 0.630 & .0001 \\
\hline Organic matter & $5.27^{\mathrm{b}}$ & $9.64^{\mathrm{a}}$ & $9.66^{\mathrm{a}}$ & $8.79^{a}$ & 0.585 & .0012 \\
\hline Crude protein & $0.150^{\mathrm{b}}$ & $0.275^{\mathrm{a}}$ & $0.278^{\mathrm{a}}$ & $0.253^{\mathrm{a}}$ & 0.0167 & .0014 \\
\hline Neutral detergent fiber & $3.79^{\mathrm{b}}$ & $6.93^{\mathrm{a}}$ & $6.95^{\mathrm{a}}$ & $6.33^{\mathrm{a}}$ & 0.421 & .0009 \\
\hline Acid detergent fiber & $2.30^{\mathrm{b}}$ & $4.20^{\mathrm{a}}$ & $4.21^{\mathrm{a}}$ & $3.83^{\mathrm{a}}$ & 0.255 & .0013 \\
\hline \multicolumn{7}{|l|}{ Total intake $(\mathrm{kg} / \mathrm{d})$} \\
\hline Dry matter & $9.13^{\mathrm{b}}$ & $13.82^{\mathrm{a}}$ & $13.86^{\mathrm{a}}$ & $12.92^{\mathrm{a}}$ & 0.630 & .0011 \\
\hline Organic matter & $8.39^{b}$ & $12.75^{\mathrm{a}}$ & $12.78^{\mathrm{a}}$ & $11.91^{\mathrm{a}}$ & 0.586 & .0013 \\
\hline Crude protein & $0.538^{\mathrm{b}}$ & $0.665^{\mathrm{a}}$ & $0.663^{\mathrm{a}}$ & $0.640^{\mathrm{a}}$ & 0.0174 & .0015 \\
\hline Neutral detergent fiber & $5.56^{\mathrm{b}}$ & $8.70^{\mathrm{a}}$ & $8.72^{\mathrm{a}}$ & $8.09^{\mathrm{a}}$ & 0.421 & .0001 \\
\hline Acid detergent fiber & $3.00^{\mathrm{b}}$ & $4.90^{\mathrm{a}}$ & $4.92^{\mathrm{a}}$ & $4.53^{\mathrm{a}}$ & 0.255 & .0001 \\
\hline \multicolumn{7}{|c|}{ Digestibility (g absorbed/kg ingested) } \\
\hline Dry matter & $557.4^{b}$ & $748.5^{\mathrm{a}}$ & $732.7^{a}$ & $723.2^{\mathrm{a}}$ & 13.42 & .0057 \\
\hline Organic matter & $577.0^{\mathrm{b}}$ & $757.3^{\mathrm{a}}$ & $741.7^{\mathrm{a}}$ & $734.5^{\mathrm{a}}$ & 13.21 & .0064 \\
\hline Crude protein & $597.4^{\mathrm{c}}$ & $741.1^{\mathrm{a}}$ & $702.6^{\mathrm{b}}$ & $695.6^{\mathrm{b}}$ & 14.17 & .0153 \\
\hline Neutral detergent fiber & $423.7^{\mathrm{b}}$ & $687.1^{\mathrm{a}}$ & $656.8^{\mathrm{a}}$ & $645.3^{\mathrm{a}}$ & 4.94 & .0029 \\
\hline Acid detergent fiber & $339.0^{\mathrm{b}}$ & $661.4^{\mathrm{a}}$ & $621.2^{\mathrm{a}}$ & $603.0^{\mathrm{a}}$ & 6.05 & .0107 \\
\hline
\end{tabular}

Abbreviations: CELL, fed the control diet plus cellulase at $10 \mathrm{~mL} /$ animal/d; control, fed oat straw and concentrates; $\mathrm{CX}$, fed the control diet plus cellulase and xylanase at $5 \mathrm{~mL}$ of CELL plus $5 \mathrm{~mL}$ of XYL/animal/d; SEM, standard error of the mean; XYL, fed the control diet plus xylanase at $10 \mathrm{~mL} /$ animal/d.

a,b,c Means in the same row with different superscript letters differ $(P<.05)$. 


\subsection{Blood Chemistry and Fecal Coliform Count}

Feeding enzymes increased blood total protein $(P=$ .0277) compared with the control. Feeding XYL-supplemented diet increased blood ALT $(P=.0314)$ and AST $(P=.0481)$ concentrations compared with control diet. No effects $(P>.05)$ were observed for blood urea, creatinine, glucose, phosphorus, magnesium, and GGT due to enzyme supplementation. Lower fecal coliform count was obtained $(P=.0114)$ with mares fed CX diet compared with mares fed control diet at the end of the experiment after 15 days (Table 2).

\subsection{In Vitro Fecal Fermentation and Digestibility}

The CELL treatment had greater asymptotic GP $(P=$ $.0173)$ with lower rate of $\mathrm{GP}(P=.0412)$ compared with $\mathrm{XYL}$ and $\mathrm{CX}$ treatments, with no difference $(P>.05)$ between CELL, XYL, CX treatments, and control treatment. Both of CELL and XYL treatments had decreased $(P=.0394)$ lag times compared with control and $\mathrm{CX}$ treatments. At 24 hours of incubation, $\mathrm{CH}_{4}$ production was decreased $(P=$ .0131) with CELL and XYL treatments compared with control and CX treatments, whereas at 48 hours of incubation, CX treatment increased $\mathrm{CH}_{4}$ production $(P=.0202)$ compared with control treatment. CELL treatment had the lowest $\mathrm{CH}_{4}$ production $(P=.0131)$ compared to other treatments (Fig. 1 ). No effect was observed $(P>.05)$ with enzymes addition on $\mathrm{CO}_{2}$ production during different incubation hours compared to control treatment (Fig. 2). Higher in vitro DMD values $(P=.0092)$ were obtained with the enzyme treatments compared with control treatment with the highest value for CELL treatment. Fermentation $\mathrm{pH}$ was lower $(P=.0396)$ with $C X$ compared with control and XYL treatments, with CELL showing a greater $\mathrm{pH}$ than the other treatments. No treatment effects $(P>.05)$ were observed on $\mathrm{CO}_{2}$ production at 24 hours of incubation, $\mathrm{ME}$, in vitro OMD, SCFA, $\mathrm{PF}_{24}, \mathrm{MCP}$, and $\mathrm{GY}_{24}$ (Table 3).

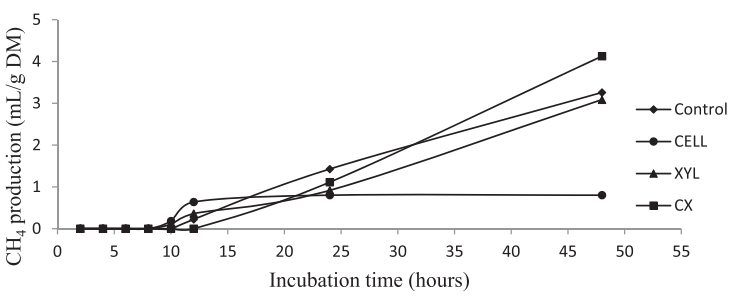

Fig. 1. Effect of addition of fibrolytic enzymes to different treatments on in vitro fecal $\mathrm{CH}_{4}$ production $(\mathrm{mL} / \mathrm{g} \mathrm{DM})$ after 48 hours of incubation. Abbreviations: CELL, control diet plus cellulase at $2 \mu \mathrm{L} / \mathrm{g} \mathrm{DM} ; \mathrm{CH}_{4}$, methane; control, oat straw and concentrate (1:1 DM) without enzyme; CX, control diet plus cellulase + xylanase $(1: 1 \mathrm{vol} / \mathrm{vol})$ at $2 \mu \mathrm{L} / \mathrm{g} \mathrm{DM}$; DM, dry matter; $\mathrm{XYL}$, control diet plus xylanase at $2 \mu \mathrm{L} / \mathrm{g} \mathrm{DM}$.

\section{Discussion}

\subsection{Feed Intake and Nutrient Digestibility}

The intake of oat straw was higher by $67 \%$ to $83 \%$ with addition of enzymes. This may be partly due to the greater nutrients digestibility with enzyme supplementation, which is consistent with previous results [9]. However, O'Connor-Robison et al [6] did not find a feed intake effect with cellulase in horse diets. To our knowledge, there are no in vivo studies available on cecal fermentation in horses. Because the large intestine of the horse is a fermentation system similar to the rumen [5], our explanations will borrow from studies with ruminant animals.

Hainze et al [8] reported reduced fiber digestibility of an enzyme-treated lucerne-based diet fed to horses and explained their results that the exogenous enzymes blocked enzyme-binding sites that would otherwise have been occupied by endogenous microbial enzymes.

In another study, Murray et al [9] fed Welsh-cross pony geldings on diet based on lucerne and enzyme addition at 8.9 L/tonne DM and reported that DM intake was significantly greater, whereas OMD was significantly reduced without affecting NDF digestibility compared with the

Table 2

Blood chemistry and total fecal coliform count of mares fed diets supplemented with cellulase, xylanase, and cellulase + xylanase (1:1 vol/vol) enzymes $(\mathrm{n}=4)$.

\begin{tabular}{|c|c|c|c|c|c|c|}
\hline \multirow[t]{2}{*}{ Items } & \multicolumn{4}{|l|}{ Diets } & \multirow[t]{2}{*}{ SEM } & \multirow[t]{2}{*}{$P$ Value } \\
\hline & Control & CELL & XYL & $\mathrm{CX}$ & & \\
\hline \multicolumn{7}{|l|}{ Blood chemistry } \\
\hline Alanine transaminase (U/L) & $12.5^{\mathrm{b}}$ & $11.8^{\mathrm{b}}$ & $20.0^{\mathrm{a}}$ & $14.8^{\mathrm{ab}}$ & 3.23 & .0314 \\
\hline Aspartate aminotransferase (U/L) & $341.0^{\mathrm{b}}$ & $389.8^{\mathrm{b}}$ & $416.8^{\mathrm{a}}$ & $384.3^{\mathrm{b}}$ & 43.93 & .0481 \\
\hline Urea (mmol/L) & 16.2 & 15.1 & 15.8 & 14.3 & 1.26 & .7330 \\
\hline Creatinine (mmol/L) & 182.0 & 184.9 & 186.3 & 170.5 & 16.17 & .3030 \\
\hline Total protein $(\mathrm{mmol} / \mathrm{L})$ & $4.49^{\mathrm{b}}$ & $5.14^{\mathrm{a}}$ & $5.09^{\mathrm{a}}$ & $5.19^{a}$ & 0.274 & .0277 \\
\hline Glucose (mmol/L) & 7.50 & 7.50 & 7.25 & 7.50 & 0.346 & .9402 \\
\hline Calcium (mmol/L) & 3.45 & 3.63 & 4.05 & 3.60 & 0.153 & .0837 \\
\hline Phosphorus (mmol/L) & 1.12 & 1.08 & 1.16 & 1.03 & 0.071 & .6386 \\
\hline Magnesium (mmol/L) & 0.65 & 0.67 & 0.71 & 0.88 & 0.056 & .4481 \\
\hline Gamma-glutamyl transpeptidase (U/L) & 16.0 & 15.8 & 15.0 & 15.5 & 0.976 & .9002 \\
\hline \multicolumn{7}{|l|}{ Fecal coliform count ( $\log _{10} / \mathrm{g}$ feces) } \\
\hline Day 0 & 7.36 & 7.48 & 7.47 & 7.45 & 0.073 & .6810 \\
\hline Day 15 & $4.26^{\mathrm{a}}$ & $4.07^{\mathrm{ab}}$ & $3.70^{\mathrm{ab}}$ & $3.53^{\mathrm{b}}$ & 0.139 & .0114 \\
\hline
\end{tabular}

Abbreviations: CELL, fed the control diet plus cellulase at $10 \mathrm{~mL} /$ animal/d; control, fed oat straw and concentrate; CX, fed the control diet plus cellulase and xylanase at $5 \mathrm{~mL}$ of CELL plus $5 \mathrm{~mL}$ of XYL/animal/d; SEM, standard error of the mean; XYL, fed the control diet plus xylanase at $10 \mathrm{~mL} /$ animal/d.

${ }_{\mathrm{a}, \mathrm{b}}$ Means in the same row with different superscript letters differ $(P<.05)$. 


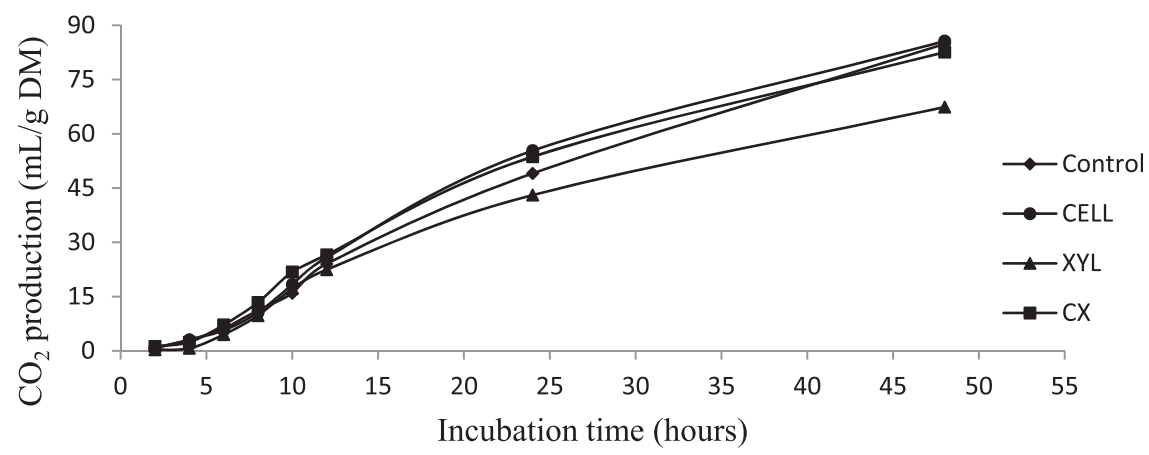

Fig. 2. Effect of addition of fibrolytic enzymes to different treatments on in vitro fecal $\mathrm{CO} 2$ production (mL/g DM) after 48 hours of incubation. Abbreviations: CELL, control diet plus cellulase at $2 \mu \mathrm{L} / \mathrm{g} \mathrm{DM} ; \mathrm{CO}_{2}$, carbon dioxide; control, oat straw and concentrate (1:1 DM) without enzyme; CX, control diet plus cellulase + xylanase (1:1 vol/vol) at $2 \mu \mathrm{L} / \mathrm{g}$ DM; DM, dry matter; XYL, control diet plus xylanase at $2 \mu \mathrm{L} / \mathrm{g} \mathrm{DM}$.

control. However, they reported that addition of enzyme at 2.3 and $4.7 \mathrm{~L} /$ ton DM resulted in a significant reduction in the apparent digestibility of OM, NDF, and total nonstarch polysaccharide digestibilities compared with control. In the present study, enzyme treatment resulted in a significant greater apparent digestibility of different nutrients relative to the control diet. Increased digestibility of enzymetreated diets has also been observed in small ruminants by others $[4,7]$.

Dietary nutrients digestion especially the fiber fraction can be affected by many factors including the chemical composition of the diet [23], the size of the indigestible fiber fraction, the digestion rate of potentially digestible fiber fractions, and rumen or cecal outflow rate, as well as the use of feed additives [7]. The suggested modes of action for the improved digestibility as a result of fibrolytic enzyme administration include increased digestion rate of the potentially digestible fiber fractions, altered fermentation kinetics, and enhanced ruminal microorganism attachment to feed particles and colonization of the plant cell wall [7,24]. Moreover, improved synergism between exogenous and endogenous enzymes [24] and increased numbers of fibrolytic and nonfibrolytic bacteria in the rumen and maybe in the cecum are other possible mechanisms.

\subsection{Blood Parameters and Fecal Coliform}

Blood parameters AST, ALT, phosphorus, and GGT were within normal physiological ranges of 212 to 449 (U/L), 3 to $23(\mathrm{U} / \mathrm{L}), 0.77$ to $1.67(\mathrm{mmol} / \mathrm{L})$, and 4 to $22(\mathrm{U} / \mathrm{L})$,

Table 3

In vitro fecal gas kinetics and cumulative gas production (mL/g DM) after 48 hours of incubation with fibrolytic enzyme addition at $2 \mu \mathrm{L} / \mathrm{g}$ DM.

\begin{tabular}{|c|c|c|c|c|c|c|}
\hline \multirow[t]{2}{*}{ Items } & \multicolumn{4}{|l|}{ Diets } & \multirow[t]{2}{*}{ SEM } & \multirow[t]{2}{*}{$P$ Value } \\
\hline & Control & CELL & XYL & $\mathrm{CX}$ & & \\
\hline$b(\mathrm{~mL} / \mathrm{g} \mathrm{DM})$ & $298.1^{\mathrm{ab}}$ & $341.3^{a}$ & $276.3^{b}$ & $284.6^{\mathrm{b}}$ & 10.14 & .0173 \\
\hline$c(\mathrm{~h})$ & $0.052^{\mathrm{ab}}$ & $0.041^{\mathrm{b}}$ & $0.057^{a}$ & $0.061^{a}$ & 0.0025 & .0412 \\
\hline$L(\mathrm{~h})$ & $2.36^{\mathrm{a}}$ & $1.80^{\mathrm{b}}$ & $1.53^{\mathrm{b}}$ & $2.12^{\mathrm{a}}$ & 0.252 & .0394 \\
\hline Gas at 2 hours & 29.3 & 26.5 & 29.6 & 32.8 & 1.38 & .0919 \\
\hline Gas at 4 hours & $55.7^{\mathrm{a}}$ & $50.9^{\mathrm{b}}$ & $56.0^{\mathrm{a}}$ & $61.8^{\mathrm{a}}$ & 2.54 & .0358 \\
\hline Gas at 6 hours & $79.4^{\mathrm{a}}$ & $73.3^{\mathrm{b}}$ & $79.6^{\mathrm{a}}$ & $87.4^{\mathrm{a}}$ & 3.51 & .0498 \\
\hline Gas at 8 hours & $100.8^{\mathrm{b}}$ & $93.9^{\mathrm{b}}$ & $100.7^{\mathrm{b}}$ & $110.0^{\mathrm{a}}$ & 4.32 & .0489 \\
\hline Gas at 10 hours & $120.1^{\mathrm{a}}$ & $112.9^{\mathrm{b}}$ & $119.4^{\mathrm{a}}$ & $130.0^{\mathrm{a}}$ & 5.00 & .0487 \\
\hline Gas at 12 hours & $137.4^{\mathrm{b}}$ & $130.4^{\mathrm{b}}$ & $136.2^{\mathrm{b}}$ & $147.7^{\mathrm{a}}$ & 5.57 & .0474 \\
\hline Gas at 24 hours & 210.7 & 209.9 & 205.1 & 218.3 & 7.50 & .9200 \\
\hline Gas at 48 hours & $271.6^{\mathrm{a}}$ & $288.9^{\mathrm{a}}$ & $257.7^{\mathrm{b}}$ & $268.7^{a}$ & 8.78 & .0342 \\
\hline Methane at 24 hours & $1.43^{\mathrm{a}}$ & $0.80^{\mathrm{b}}$ & $0.92^{\mathrm{b}}$ & $1.11^{\mathrm{a}}$ & 0.0521 & .0131 \\
\hline Methane at 48 hours & $3.26^{\mathrm{b}}$ & $0.80^{c}$ & $3.09^{\mathrm{b}}$ & $4.13^{\mathrm{a}}$ & 0.677 & .0202 \\
\hline Carbon dioxide at 24 hours & 49.04 & 55.36 & 43.08 & 53.69 & 10.981 & .8411 \\
\hline Carbon dioxide at 48 hours & 84.85 & 85.65 & 67.40 & 82.58 & 14.117 & .2212 \\
\hline $\mathrm{pH}$ & $6.84^{\mathrm{b}}$ & $6.97^{\mathrm{a}}$ & $6.81^{\mathrm{b}}$ & $6.69^{c}$ & 0.022 & .0396 \\
\hline ME (MJ/kg DM) & 8.33 & 8.31 & 8.17 & 8.53 & 0.204 & .9194 \\
\hline In vitro OMD (mg/g DM) & 560.2 & 558.7 & 550.1 & 573.7 & 13.33 & .9201 \\
\hline In vitro DMD (mg/g DM) & $533.3^{c}$ & $580.0^{\mathrm{a}}$ & $543.3^{b}$ & $546.7^{\mathrm{b}}$ & 4.37 & .0092 \\
\hline SCFA (mmol/g DM) & 4.66 & 4.64 & 4.53 & 4.83 & 0.166 & .9204 \\
\hline $\mathrm{PF}_{24}$ (mg DMD/mL gas) & 5.39 & 5.41 & 5.42 & 5.35 & 0.049 & .9573 \\
\hline MCP (mg/g DM) & 670.1 & 668.5 & 659.4 & 684.2 & 14.02 & .9200 \\
\hline $\mathrm{GY}_{24}$ (gas/g DMD) & 185.7 & 185.0 & 184.5 & 187.0 & 1.67 & .9498 \\
\hline
\end{tabular}

Abbreviations: $b$, asymptotic gas production; $c$, rate of gas production; CELL, control diet plus cellulase at $2 \mu \mathrm{L} / \mathrm{g}$ DM; control, oat straw and concentrate (1:1 $\mathrm{DM}$ ) without enzyme; CX, control diet plus cellulase + xylanase (1:1 vol/vol) at $2 \mu \mathrm{L} / \mathrm{g}$ DM; DM, dry matter; GP, gas production; GY24, gas yield at 24 hours of incubation; in vitro DMD, in vitro dry matter degradability; in vitro OMD, in vitro organic matter digestibility; $L$, initial delay before gas production begins; MCP, microbial crude protein production; ME, metabolizable energy; $\mathrm{PF}_{24}$, partitioning factor at 24 hours of incubation; SCFA, short-chain fatty acid; SEM, standard error of the mean; XYL, control diet plus xylanase at $2 \mu \mathrm{L} / \mathrm{g} \mathrm{DM}$.

a,b,c Means in the same row with different superscript letters differ $(P<.05)$. 
respectively, as per the manufacturer kit. Blood content of total protein and magnesium was slightly lower than the provided normal physiological range of 5.3 to $7.1(\mathrm{mmol} / \mathrm{L})$ and 0.90 to $1.14(\mathrm{mmol} / \mathrm{L})$, whereas blood content of urea, creatinine, glucose, and calcium were greater than normal physiological range of 4.1 to $7.6,88$ to $156,3.4$ to 6.2 , and 2.8 to $3.2(\mathrm{mmol} / \mathrm{L})$, respectively, but without significant differences between treatments. Values greater than normal physiological range may be due to normal and individual differences between horses as the control horses were not different from the treated horses. The lack of difference in urea and creatinine concentrations between treated and control horses suggests no catabolism of muscles protein and that the kidney function was not adversely affected by any the diets [25]. Generally, serum creatinine is an indicator of glomerular filtration in the kidney [25]. The higher glucose concentration observed compared to the normal physiological range may be due to increased OM, NDF, and ADF digestibilities resulting in enhanced energy utilization and increased propionate absorption through cecum wall, leading to a high rate of glucose synthesis.

Addition of XYL elevated liver enzymes of ALT and AST concentrations, but these were within normal physiological ranges of both ALT and AST enzymes, which are important indicators of liver activity and function suggesting there were no pathologic lesions in the liver [26]. Blood total protein was higher with enzyme addition to the diet than with the control. Increased total protein in the serum reflects a good nutritional status in the horses because there is a positive correlation between blood total protein and dietary protein intake [27]. Moreover, it would be possibly due to the greater $\mathrm{CP}$ intake and digestibility observed with fibrolytic enzymes addition [7].

At day 15 of the experiment, feeding horses with a mixture of cellulase and xylanase (i.e., CX treatment) lowered the fecal shedding of $E$. coli by about $17 \%$ compared with control. Pathogenic bacteria such as E. coli are known to cause intestinal diseases in horses [28]. However, there is limited information available on the microbial burden of equine feces. Nutrition is among the major factors influencing the conditions in the rumen and cecum. A relation between diet and the proliferation and resistance of $E$. coli has been suggested [29]. The energy content of the diet and the manner in which it is fermented in the rumen or cecum play a critical role in maintaining bacterial populations [30]. Feeding enzymes may improve the feed utilization and stimulate the immune response in the host animal as shown with the enzyme treatment as the fecal shedding of E. coli was decreased by about $17 \%$ compared to control with the CX treatment; however, there were no significant differences for CELL and XYL. Another probable reason is a lowered cecal $\mathrm{pH}$ as shown in the in vitro fecal fermentation where CX treatment had the lowest $\mathrm{pH}$ [31].

\subsection{In Vitro Fecal Fermentation and Digestibility}

The cellulase treatment (i.e., CELL) had the highest asymptotic GP and the lowest rate of GP. Administrations of exogenous fibrolytic enzymes have been shown to increase in vitro GP and the nutritive value of feeds with ruminal inoculum from cattle [32]. However, in the present study, only cellulase had any effect. Xylanase and cellulose and/or xylanase mixture had no effect. This may be related to the nature of the diet [32] or the fecal inocula used. The higher GP with CELL may allow greater voluntary feed intake by decreasing cecum physical fill and increasing the net energy intake of the diets [33]. The volume of GP reflects the fermentation potential of the diet and depends on nutrient availability for inocula microorganisms during fermentation [23]. Exogenous enzymes can enhance attachment of microorganisms to feed particles, creation of a stable enzyme-feed complexes [34], and/or the possibility of the fiber structure alteration within the cecum causing microbial colonization to feeds. In general, the enzyme effects are dependent on many factors such as source, type and dose of enzyme, type of diets fed to the animals, and enzyme application method [35]. In the present study, two different enzyme products were used with different responses; however, enzymes were used at the same dose and the same diet. Different enzyme products and different enzyme sources can explain the different response to the different tested enzyme products in the present study. The ability of CELL, XYL, or their mixture to increase fiber digestion may be limited by the lack of enzymes that degrade the core structure of lignin-cellulose complexes in low-quality forages [35].

Enzyme addition (CELL in the present study) may cause improved cecal fermentation and enhance attachment and colonization of cecal microorganisms to the plant cell wall and work in synergism with cecal endogenous microbial enzymes as previously mentioned.

Higher in vitro DMD values were obtained with enzyme treatments compared with control. Nsereko et al [36] showed that the increased DMD of diets with the addition of enzymes may have been due to increased fiber digestion and altered fermentation, enhanced attachment and colonization to the plant cell wall material by microorganisms. Results of in vitro DMD support those obtained in vivo (Tables 1 and 3).

At 24 hours of incubation, CELL and XYL decreased $\mathrm{CH}_{4}$ production, while at 48 hours of incubation higher $\mathrm{CH}_{4}$ production was observed with the $\mathrm{CX}$ treatment, and lower $\mathrm{CH}_{4}$ production was observed with CELL treatment. Fermentation of dietary carbohydrates to acetate, propionate, and butyrate produce gases which mainly constitutes $\mathrm{H}_{2}, \mathrm{CO}_{2}$, and $\mathrm{CH}_{4}$. During the first 12 hours of incubation, $\mathrm{CH}_{4}$ production was negligible and then it started to increase rapidly to reach its peak concentration at the end of incubation. However, GP started with the onset of incubation. In general, $\mathrm{CH}_{4}$ yields for horses are between those for pigs and for ruminants and they equal $3 \%$ to $4 \%$ of the digestible energy or $2 \%$ to $3 \%$ of the gross energy intake [37]. In both ruminants and horses, $\mathrm{CH}_{4}$ is mainly produced by the methanogenic archaea, which represent the main hydrogenotrophic microbial community [38].

\section{Conclusions}

Addition of fibrolytic enzyme of cellulase, xylanase, and their mixture $(1: 1 \mathrm{vol} / \mathrm{vol})$ at $10 \mathrm{~mL} /$ animal/d resulted in greater intake of oat straw. Improved feed intake was coupled with increased nutrient digestibilities. Blood 
parameters were altered by the treatments with lower fecal shedding of $E$. coli of about $17 \%$ with the treatment of cellulase and/or xylanase mixture. In vitro fecal fermentation showed higher GP and DMD with enzyme treatment with the better results with cellulase addition at $2 \mu \mathrm{L} / \mathrm{g} D M$ of the substrate. These results show that addition of fibrolytic enzymes at $10 \mathrm{~mL} / \mathrm{mare} / \mathrm{d}$ improved feed intake and nutrients digestibility without affecting mare's health.

\section{Acknowledgments}

The authors acknowledge the financial support from the IAEA, Vienna, Austria (Research Contract Number MEX16307 within the D3.10.27 Coordinated Research Project). Kholif, A.E. thanks the National Council for Science and Technology (CONACyT, Mexico) and The World Academy of Sciences (TWAS, Italy) to support his Postdoctoral fellowship at the Facultad de Medicina Veterinaria y Zootecnia, Universidad Autónoma del Estado de México.

\section{References}

[1] Rowe JB, Lees MJ, Pethick DW. Prevention of acidosis and laminitis associated with grain feeding in horses. J Nutr 1994;124: 2742S-4S.

[2] National Research Council, Nutrient requirements of horses. 4th ed. Washington, DC: National Academy Press; 1978.

[3] Elghandour MMY, Vázquez Chagoyán JC, Salem AZM, Kholif AE, Martínez Castañeda JS, Camacho LM, Buendía G. In vitro fermentative capacity of equine fecal inocula of 9 fibrous forages in the presence of different doses of Saccharomyces cerevisiae. J Equine Vet Sci 2014;34:619-25.

[4] Alsersy H, Salem AZM, Borhami BE, Olivares J, Gado HM, Mariezcurrena MD, Yacuot MH, Kholif AE, El-Adawy M, Hernandez SR. Effect of Mediterranean saltbush (Atriplex halimus) ensilaging with two developed enzyme cocktails on feed intake, nutrient digestibility and ruminal fermentation in sheep. Anim Sci J 2015;86:51-8.

[5] Tisserand JL. Microbial digestion in the large intestine in relation to monogastric and polygastric herbivores. Acta Vet Scand Suppl 1989; 86:83-92.

[6] O'Connor-Robison CI, Nielsen BD, Morris R. Cellulase supplementation does not improve the digestibility of a high-forage diet in horses. J Equine Vet Sci 2007;27:535-8.

[7] Khattab HM, Gado HM, Kholif AE, Mansour AM, Kholif AM. The potential of feeding goats sun dried rumen contents with or without bacterial inoculums as replacement for berseem clover and the effects on milk production and animal health. Int J Dairy Sci 2011;6:267-77.

[8] Hainze MTM, Muntifering RB, McCall CA. Fiber digestion in horses fed typical diets with and without exogenous fibrolytic enzymes. J Equine Vet Sci 2003;23:111-5.

[9] Murray JMD, Longland A, Davies DR, Hastie PM, Moore-Colyer M, Dunnett $C$. The effect of enzyme treatment on the nutritive value of lucerne for equids. Livest Sci 2007;112:52-62.

[10] Robyt JF, Whelan WJ. Reducing value methods for maltodextrins: 1 . Chain length dependence of alkaline 3,5-dinitrosalicylate and chain length independence of alkaline copper. Anal Biochem 1972;45: 510-6.

[11] Agazzi A, Ferroni M, Fanelli A, Maroccolo S, Invernizzi G, Dell'Orto V, Savoini G. Evaluation of the effects of live yeast supplementation on apparent digestibility of high-fiber diet in mature horses using the acid insoluble ash marker modified method. J Equine Vet Sci 2011; 31:13-28.

[12] Association of Official Analytical Chemists (AOAC). Official methods of analysis. 16th ed. Arlington, VA, USA: AOAC; 1997.

[13] Van Soest PJ, Robertson JB, Lewis BA. Methods for dietary fibre, neutral detergent fibre, and non-starch carbohydrates in relation to animal nutrition. J Dairy Sci 1991;74:3583-97.

[14] Van Keulen J, Young BA. Evaluation of acid-insoluble ash as a natural marker in ruminant digestibility studies. J Anim Sci 1977;44:282-7.

[15] Weaver RW, Entry JA, Graves A. Numbers of fecal streptococci and Escherichia coli in fresh and dry cattle, horse, and sheep manure. Can J Microbiol 2005;51:847-51.
[16] Theodorou MK, Williams BA, Dhanoa MS, McAllan AB, France J. A simple gas production method using a pressure transducer to determine the fermentation kinetics of ruminant feeds. Anim Feed Sci Technol 1994;48:185-97.

[17] Goering MK, Van Soest PJ. Forage fiber analysis (apparatus, reagents, procedures and some applications). Agriculture Handbook, No 379. Washington, DC: Agricultural Research Service, USDA; 1970.

[18] Co SAS. User's guide: statistics, version 9.0. Cary, NC: SAS Institute; 2002.

[19] France J, Dijkstra J, Dhanoa MS, López S, Bannink A. Estimating the extent of degradation of ruminant feeds from a description of their gas production profiles observed in vitro: derivation of models and other mathematical considerations. Br J Nutr 2000;83: $143-50$.

[20] Menke KH, Raab L, Salewski A, Steingass H, Fritz D, Schneider W. The estimation of the digestibility and metabolizable energy content of ruminant feedstuffs from the gas production when they are incubated with rumen liquor in vitro. J Agr Sci 1979;92: 217-22.

[21] Blümmel M, Steingss H, Becker K. The relationship between in vitro gas production, in vitro microbial biomass yield and ${ }^{15} \mathrm{~N}$ incorporation and its implications for the prediction of voluntary feed intake of roughages. Br J Nutr 1997;77:911-21.

[22] Getachew G, Makkar HPS, Becker K. Tropical browses: contents of phenolic compounds, in vitro gas production and stoichiometric relationship between short chain fatty acid and in vitro gas production. J Agr Sci 2002;139:341-52.

[23] Elghandour MM, Vázquez Chagoyán JC, Salem AZM, Kholif AE, Martínez Castañeda JS, Camacho LM, Cerrillo-Soto MA. Effects of Saccharomyces cerevisiae at direct addition or pre-incubation on in vitro gas production kinetics and degradability of four fibrous feeds. Ital J Anim Sci 2014;13:295-301.

[24] Wang Y, McAllister TA, Rode LM, Beauchemin KA, Morgavi DP, Nsereko VL, Iwaasa AD, Yang W. Effects of an exogenous enzyme preparation on microbial protein synthesis, enzyme activity and attachment to feed in the rumen simulation technique (Rusitec). Br J Nutr 2001;85:325-32.

[25] Hosten AO. BUN and Creatinine. In: Walker HK, Hall WD, Hurst JW, editors. Clinical methods: the history, physical, and laboratory examinations. Boston, MA: Butterworths; 1990. p. 874-8.

[26] Pettersson J, Hindorf U, Persson P, Bengtsson T, Malmqvist U, Werkström V, Ekelund M. Muscular exercise can cause highly pathological liver function tests in healthy men. Br J Clin Pharmacol 2008;65:253-9.

[27] Banh L. Serum proteins as markers of nutrition: what are we treating? Pract Gastroenterol 2006;30:46-64.

[28] Diab SS, Kinde H, Moore J, Shahriar MF, Odani J, Anthenill L, Songer G, Uzal FA. Pathology of Clostridium perfringens type C enterotoxemia in horses. Vet Pathol 2012;49:255-63.

[29] Su R, Munns K, Beauchemin KA, Schwartzkopf-Genswein K, JinQuan L, Topp E, Sharma R. Effect of backgrounding and transition diets on fecal concentration and strain types of commensal Escherichia coli in beef cattle. Can J Anim Sci 2011;91:449-58.

[30] Kennelly JJ, Robinson B, Khorasani GR. Influence of carbohydrate source and buffer on rumen fermentation characteristics, milk yield, and milk composition in early-lactation Holstein cows. J Dairy Sci 1999;82:2486-96.

[31] Denev SA, Peeva TZ, Radulova P, Stancheva N, Staykova Beev G, Todorova P, Tchbanova S. Yeast cultures in ruminant nutrition. Bulg J Agr Sci 2007;13:357-74.

[32] Elghandour MMY, Kholif AE, Márquez-Molina O, Vázquez-Armijo JF Puniya AK, Salem AZM. Influence of individual or mixed cellulase and xylanase mixture on in vitro rumen gas production kinetics of total mixed rations with different maize silage and concentrate ratios. Turk J Vet Anim Sci 2015;39:435-42.

[33] Oba M, Allen MS. Effects of brown midrib 3 mutation in corn silage on productivity of dairy cows fed two concentrations of dietary neutral detergent fiber: 3. Digestibility and microbial efficiency. J Dairy Sci 2000;83:1350-8.

[34] Kung Jr L, Treacher RJ, Nauman GA, Smagala AM, Endres KM Cohen MA. The effect of treating forages with fibrolytic enzymes on its nutritive value and lactation performance of dairy cows. J Dairy Sci 2000;83:115-22.

[35] Giraldo LA, Carro MD, Ranilla MJ, Tejido ML, Mohamed AH. In vitro ruminal fermentation of low-quality forages as influenced by the treatment with exogenous fibrolytic enzymes. In: Priolo A, Biondi L, Ben Salem H, Morand-Fehr P, editors. Advanced nutrition and feeding strategies to improve sheep and goat. Zaragoza, Spain: CIHEAM; 2007. p. 263-7. 
[36] Nsereko VL, Beauchemin KA, Morgavi DP, Rode LM, Furtado AF, McAllister TA, Iwaasa AD, Yang WZ, Wang Y. Effect of a fibrolytic enzyme preparation from Trichoderma longibrachiatum on the rumen microbial population of dairy cows. Can J Microbiol 2002;48: 14-20.
[37] Kirchgessner M. Animal nutrition. 6th edition. Frankfurt: DLG publisher; 1985. p. 488.

[38] Wolin MJ, Miller TL, Stewart CS. Microbe-microbe interactions. In: Hobson PN, Stewart CS, editors. The rumen microbial ecosystem. London, UK: Chapman \& Hall; 1997. p. 467-91. 